\title{
Screening test for Dendropanax morbifera Leveille extracts: in vitro comparison to ox-LDL-induced lipid accumulation, ethanol-induced fatty liver and HMG-CoA reductase inhibition
}

\author{
Ji Sun Youn ${ }^{1} \cdot$ Min Seo Kim ${ }^{1} \cdot$ Hye Jin $\mathrm{Na}^{2} \cdot$ Hae Rim Jung ${ }^{2}$ Chang Khil Song \\ - So Young Kang ${ }^{3} \cdot$ Ji Yeon $\mathrm{Kim}^{1}$ (iD
}

\section{황칠나무 추출물의 고지혈증 완화 효과 스크리닝}

윤지선 ${ }^{1}$ - 김민서 ${ }^{1}$ - 나혜진 ${ }^{2}$ - 정해 림 ${ }^{2}$ - 송창길 ${ }^{3}$ - 강소영 ${ }^{3}$ - 김지연 ${ }^{1}$

\begin{abstract}
The objective of this study was to compare the antihyperlipidemic effects of different Dendropanax morbifera leaf extracts in vitro. The extracts differed in terms of specimen age, harvesting season, and extraction method. RAW 264.7 cells were pretreated with these extracts and stimulated by oxidized low-density lipoprotein. Ethanol was used to induce toxicity in HepG2 cells. Cellular lipid accumulation was quantified using oil red $\mathrm{O}$ staining in both these cells. The extracts were evaluated for their inhibitory effects on 3-hydroxy-3-methylglutaryl coenzyme A (HMG-CoA) reductase. RAW 264.7 cells treated with the $60 \%$ ethanol extract of an 8-year-old specimen harvested in November exhibited the lowest lipid accumulation. The 30\% ethanol extract of a 5-year-old specimen harvested in May exhibited the greatest
\end{abstract}

Ji Yeon Kim $(\square)$

E-mail: jiyeonk@seoultech.ac.kr

${ }^{1}$ Department of Food Science and Technology, Seoul National University of Science and Technology; 232, Gongneung-ro, Nowon-gu, Seoul 01811, Republic of Korea

${ }^{2}$ Korea Food Information Institute, Banseok-ro, Yuseong-gu, DaeJeon 34068, Republic of Korea

${ }^{3}$ Agency for Jeju Plant Resources Dendropanax, Jejuuniversity-ro, Jeju 63243, Republic of Korea

This is an Open Access article distributed under the terms of the Creative Commons Attribution Non-Commercial License (http://creativecommons. org/licenses/by-nc/3.0/) which permits unrestricted non-commercial use, distribution, and reproduction in any medium, provided the original work is properly cited. protection from ethanol-induced cytotoxicity in HepG2 cells. The hot water extract of an 8-year-old specimen harvested in May showed the greatest inhibition of HMG-CoA reductase. These results showed that $D$. morbifera extracts prepared from leaves that are harvested in May possess the highest antihyperlipidemic effects.

Keywords Dendropanax morbifera · 3-hydroxy-3-methylglutaryl coenzyme A reductase - Hyperlipidemia - Lipid accumulation . Oxidized low density lipoprotein

\section{서 론}

심혈관계 질환은 최근 현대인들의 생명을 위협하는 질환으로, 전체 사망률 중 $15.8 \%$ 로 높은 비율을 차지하고 있다(Lo 등, 2017). 이 질환은 고지혈증과 고혈압 등이 위험요인으로 간주되 는데(Goldstein 등, 1973; Ramoglu 등, 2017), 우리나라에서도 외식문화의 발달과 함께 변화된 고지방 식습관으로 인해 고지 혈증의 위험이 증가하는 추세이다. 고지혈증은 체내 콜레스테롤 이 많은 상태를 말하며체내 콜레스테롤의 약 $70 \%$ 는 내인성 생 합성으로 생성된다. 그 중 3-hydroxy-3-methylglutaryl coenzyme A (HMG-CoA)가 콜레스테롤 합성의 전구체로서 생합성에 관 여한다(Lin 등, 2015). Acetyl-CoA와 acetoacetyl-CoA의 축합반 응으로 생성된 $\mathrm{HMG}-\mathrm{CoA}$ 가 mevalonate로 환원될 때 HMG$\mathrm{CoA}$ reductase (HMGCR)가 촉매제로 작용된다(Kim 등, 2014). 촉매제인 $\mathrm{HMGCR}$ 의 활성을 저해하면 체내 콜레스테롤 
의 합성 속도를 조절 할 수 있는 것으로 보고된다(Choi 등, 2013; Hwang 등, 2017). 또한 체내에서 콜레스테롤 축적이 지 속되면 간 세포 내에서 신호 전달 경로의 활성화를 통해 간 손 상을 유발한다. 간 세포에 지방이 축적되어 손상을 유발한 지 방간은 고지혈증, 고혈압, 제2형당뇨, 암 등 생활과 밀접한 질 병과 관련되어, 결국에는 심혈관계 질환까지 일으킨다(Perla 등, 2017; Xu 등, 2017). 또한 고지혈증은 저밀도지단백질의 산화로 인해 발병하기도 한다. 대식세포는 산화되는 저밀도지단백질을 흡수하여 주요 지질을 함유하는 세포인 거품세포로 전환된다 (Xu 등, 2017). 전환된 거품세포가 혈관 내막에 쌓이면서 혈류 를 막게 되고, 막힌 혈관에 의해 죽상 동맥 경화증이 발병하게 된다(Liu 등, 2017). 이렇게 생명을 위협할 수 있는 고지혈증을 예방하기 위해서는 개인의 식습관 변화와 더불어 체내 콜레스 테롤과 같은 지방성분의 대사과정을 조절할 수 있는 천연 식품 소재를 찾으려는 노력이 계속되어야 한다.

황칠나무(Dendropanax morbifera Leveille)는 두릅나무과 (Araliaceae)에 속하며 겨울에도 낙엽이 지지 않는 수종이다. 예 로부터 황칠은 주로 도료의 원료로서 사용되어 왔다( $\mathrm{Mo}$ 와 $\mathrm{Oh}$ 2013). 황칠나무의 주요 기능으로 알려진 항당뇨 - 항염증 효과 에 대한 연구(Moon 2011; Akram 등, 2016) 외에도 고지방 식 이를 급여한 마우스의 지질 개선 효과에 대해서 보고되어 있다 (Tan과 Ho 2015), 황칠나무 성분에는 지질대사 개선 효과가 있 는 것으로 알려진 Tiliroside (Qiao 등, 2011), 혈중 콜레스테롤 수치를 낮춰주는 식물성 스테롤의 일종인 $\beta$-sitosterol (Rudkowska 등, 2008) 등이 함유되어 있는 것으로 보고되었다 (Chung 등, 2011; Lee 등, 2015). 하지만 황칠나무 추출물의 지질대사 개선 효과에 대한 연구는 미비한 실정이다.

본 연구에서는 황칠나무의 부위, 그리고 추출 용매의 종류 및 비율, 황칠나무의 채취시기에 따른 산화 저밀도지단백질로 유도 된 대식세포에서의 지질 축적, 에탄올로 유도된 간세포에서의 지질 축적, 그리고 $\mathrm{HMGCR}$ 억제 능력을 스크리닝하여 지질대 사 개선효과를 보이는 추출물을 탐색하고자 하였다.

\section{재료 및 방법}

\section{실험 재료}

본 실험에 사용한 황칠나무(D. morbifera)는 (사)제주자원식물황 칠사업단으로부터 공급받아 사용하였다. (주)한국식품정보원에서 전처리한 황칠시료를 이용해 실험을 진행하였다. 시료의 전처리 과정은 황칠나무에서 채취한 성숙잎을 물과 발효주정을 이용하 여 각각의 추출수율이 높은 조건으로 가열 교반 추출하였다. 감 압 여과와 농축을 거친 후 동결건조기(Ilshinbiobase Co. Ltd., Dongducheon, Korea)에서 48시간 건조한 후 완전히 분쇄해 황 칠나무 추출분말을 제조하여 실험에 사용하였다.

\section{시약}

Fetal bovin serum (FBS), Penicillin-streptomycin, Dulbecco modified eagle medium (DMEM), Dulbecco's phosphate buffered saline (DPBS)은 Biowest (Nuaillé, Cholet, France)의 제품을, (4-(2-hydroxyethyl)-1-piperazineethanesulfonic acid (HEPES)는 Gibco (Rockville, MD, USA) 제품을 사용하였다. 3-(4,5-dimethyl-
2-thiazolyl)-2,5-diphenyl-2H-tetrazolium bromide (MTT), HMGCoA reductase assay kit, lipoprotein-deficient human serum, isopropanol, Oil Red O (ORO)는 Sigma-Aldrich (St. Louis, $\mathrm{MO}, \mathrm{USA}$ )에서 구매하였다. Dimethyl sulfoxide (DMSO)는 Junsei Chemical Co., Ltd. (Tokyo, Japan) 제품을 사용하였다. Oxidized low density lipoprotein (ox-LDL)는 Cell biolabs, Inc. (San Diego, CA, USA)에서, 4\% paraformaldehyde는 Biosesang (Seongnam, Korea)에서 구매하였다.

\section{세포주 배양}

마우스 대식세포인 RAW 264.7 cell과 인간 간암 세포주 (human liver hepatocellular carcinoma cell line)인 HepG2 cell은 한국세포주은행(KCLB, Seoul, Korea)에서 배양 받아 사 용하였다. 시료의 체내 LDL 산화 억제에 미치는 영향을 알아 보기 위해 RAW 264.7 cell을, 간에서의 지질 축적 억제를 확 인하기 위해 HepG2 cell을 이용하였다. 두 세포는 $10 \% \mathrm{FBS}$, $2 \%$ Penicillin-streptomycin, 2\% HEPES 을 포함한 DMEM 배 지에서 $37{ }^{\circ} \mathrm{C}, 5 \% \mathrm{CO}_{2}$ incubator에서 같은 조건으로 배양하였 다. 배지는 48-72시간 주기로 갈아주었고, 세포가 cell dish의 $80 \%$ 이상 자라면 계대하였다.

\section{세포독성 측정}

시료에 의한 세포독성을 알아보기 위해 MTT assay 방법을 이 용하였다(Jun 등, 2012). 배양한 HepG2 cell과 RAW 264.7 cell를 각각 96well plate에 $1 \times 10^{5}$ cell $/ \mathrm{mL}$ 농도로 $200 \mu \mathrm{L}$ 씩 분 주하여 24시간 동안 배양하였다. HepG2 cell, RAW 264.7 cell 에 황칠 추출물을 각각 $12.5,25,50,100 \mu \mathrm{g} / \mathrm{mL}$ 농도의 황칠 나무 추출물을 처리한 후 12시간 반응시켰다. $5 \mathrm{mg} / \mathrm{mL}$ (DPBS) 의 MTT 시약을 $20 \mu \mathrm{L}$ 씩 분주 한 후 2 시간 incubator에서 반 응시켰다. 상층액을 제거 후 살아있는 세포의 양과 비례한 formazon을 DMSO $100 \mu \mathrm{L}$ 씩 처리해 용해시켰다. 마이크로 판 독기(BioTekInstruments, Inc., Winooski, Vermont, USA)로 $560 \mathrm{~nm}$ 에서 흡광도를 측정하였다.

\section{산화 저밀도지단백질 억제 정도 측정}

황칠나무 추출물을 대식세포에 처리하여 거품세포 형성에 중요 한 기전인 산화 저밀도지단백질(ox-LDL)을 얼마나 저해할 수 있는지 확인하였다. RAW 264.7 cell을 24well plate에 $1 \times 10^{5}$ $\mathrm{cell} / \mathrm{mL}$ 농도로 $1 \mathrm{~mL}$ 씩 분주하여 48시간 동안 배양하였다. $5 \%$ lipoprotein-deficient human serum, ox-LDL $50 \mu \mathrm{g} / \mathrm{mL}$ 를 첨가 한 배지로 교체한 후 시료를 처리하여 24시간 반응시켰다 $(\mathrm{Wu}$ 등, 2014a). 4\% paraformaldehyde로 30분간 세포를 고정시켰다. $60 \%$ isopropanol로 세척 후 ORO 용액으로 1시간 동안 세포를 염색하였다. 다시 $60 \%$ isopropanol로 세척하고, 염색된 세포를 현미경으로 관찰 후 $100 \%$ isopropanol $1 \mathrm{~mL}$ 를 10 분간 처리하 여 세포 중 염색된 지방질만을 추출하였다 $(\mathrm{Xu}$ 등, 2010). 96well plate에 $300 \mu \mathrm{L}$ 씩 분주하여 마이크로 판독기로 $385 \mathrm{~nm}$ 에서 흡광도를 측정하였다.

\section{간세포 지방 축적 억제 측정}

HepG2 cell을 24 well plate에 $1 \times 10^{5}$ cell $/ \mathrm{mL}$ 농도로 $1 \mathrm{~mL}$ 씩 분주하여 48 시간 동안 배양하였다. 간 독성을 유도하기 위해 에 
탄올 $96 \mu \mathrm{L} / \mathrm{mL}$ 를 첨가한 배지로 교체한 후 시료를 처리하여 24시간 반응시켰다. ORO 염색방법을 이용해 세포 중 염색된 지방질을 추출하고, $510 \mathrm{~nm}$ 에서 흡광도를 측정하였다(Yao 등, 2011).

\section{HMG-CoA reductase 저해 활성 측정}

HMGCR assay kit는 nicotinamide adenine dinucleotide phosphate $(\mathrm{NADP}+)$ 의 생성 정도를 측정해 시료의 $\mathrm{HMGCR}$ 저해 활성을 확인하였다(Hwang 등, 2017). 실험의 양성대조군으로 고지혈증 치료제로 잘 알려진 Pravastatin $50 \mathrm{nM}$ 을 사용했다. 측정방법은 assay buffer $181 \mathrm{~mL}$ 에 시료를 $1 \mathrm{~mL}$ 가했다. 이어 $\mathrm{NADPH} 4$ $\mathrm{mL}, \mathrm{HMG}-\mathrm{CoA} 12 \mathrm{~mL}, \mathrm{HMGCR} 2 \mathrm{~mL}$ 를 넣은 후 잘 섞어주 었다. 마이크로 판독기를 이용해 $340 \mathrm{~nm}$ 에서 흡광도를 측정하 였다.

\section{High Pressure Liquid Chromatography를 이용한 주요 플라 보노이드 분석}

High Pressure Liquid Chromatography (HPLC) 분석은 방법은 페놀 성분 분석을 기초로 하였다(Coseteng과 Lee 1987). 이 분 석은 Shiseido Capcell Pak C18 MG II S-5 $(250 \times 4.6 \mathrm{~mm}$, i.d., $5 \mu \mathrm{m}$ ) 컬럼이 장착 된 Shiseido SI-2 시리즈 HPLC 시스 템(Shiseido, Tokyo, Japan)을 사용하였다. 3\% (v/v) 아세트산이 녹아 있는 증류수(용매 $\mathrm{A})$ 와 메탄올(용매 $\mathrm{B}$ )로 이루어진 이동 상을 다음과 같은 방법으로 진행하였다: $0-8$ 분, $0-10 \%(\mathrm{~B})$; 830 분, $10-55 \%$ (B); 30-36분, $55-0 \%$ (B); 36-40분, $0 \%$ (B)의 재 평형을 유속 $1.0 \mathrm{~mL} /$ 분 및 주입 부피 $10 \mu \mathrm{L}$ 로 수행 하였다. 모든 크로마토그래피 조작은 $40{ }^{\circ} \mathrm{C}$ 에서 수행되었다. Chlorogenic acid와 rutin의 검출 파장은 $280 \mathrm{~nm}$ 로 설정하였다. D. morbifera 의 추출물에서 chlorogenic acid와 rutin은 외부 표준물질과 검 출 시간을 대조하여 검증하였으며, chlorogenic acid와 rutin을 혼합한 표준 혼합 표준 용액을 메탄올을 용매로 하여 제조했다. $0.00625-0.1 \mathrm{mg} / \mathrm{mL}$ 의 농도 범위에서 표준 검량선을 만들었다. 황칠나무 잎 추출물은 메탄올 $200 \mu \mathrm{L}$ 에 녹인 뒤 여과하고 HPLC 시스템에 주입했다.

\section{통계처리}

실험 결과는 SPSS software (20.0, SPSS Inc., Chicago, IL, $\mathrm{USA}$ )의 일원배치 분산분석을 이용하여 $p<0.05$ 수준에서 통계 처리 하였으며, Duncan's multiple range test로 시료간의 유의 적 차이를 검증하였다.

\section{결과 및 고찰}

\section{세포 독성 비교}

본 실험에서 사용한 시료는 식품에서 사용 가능한 용매인 주정 및 물을 이용하여 추출하였다. 주정을 이용한 미나리 추출물에 서 에탄올의 농도가 높아질수록 수율이 감소한다는 보고가 있 고(Won 등, 2015), 70\% 에탄올로 추출한 황칠나무의 항암효과, 항당뇨 효과 등 다양한 활성 연구도 있다(Lee 등, 2013; An 등, 2014; Choi 등, 2015). 따라서 본 연구에서는 식품에 주정 농도 를 수율과 활성을 고려하여 30 과 $60 \%$ 로 결정하여 추출하였다. 실험 조건을 확립하기 위해 RAW 264.7 세포와 HepG2 세포에 대한 세포 독성을 확인하였다. 황칠나무 잎 추출물을 $50 \mu \mathrm{g} / \mathrm{mL}$
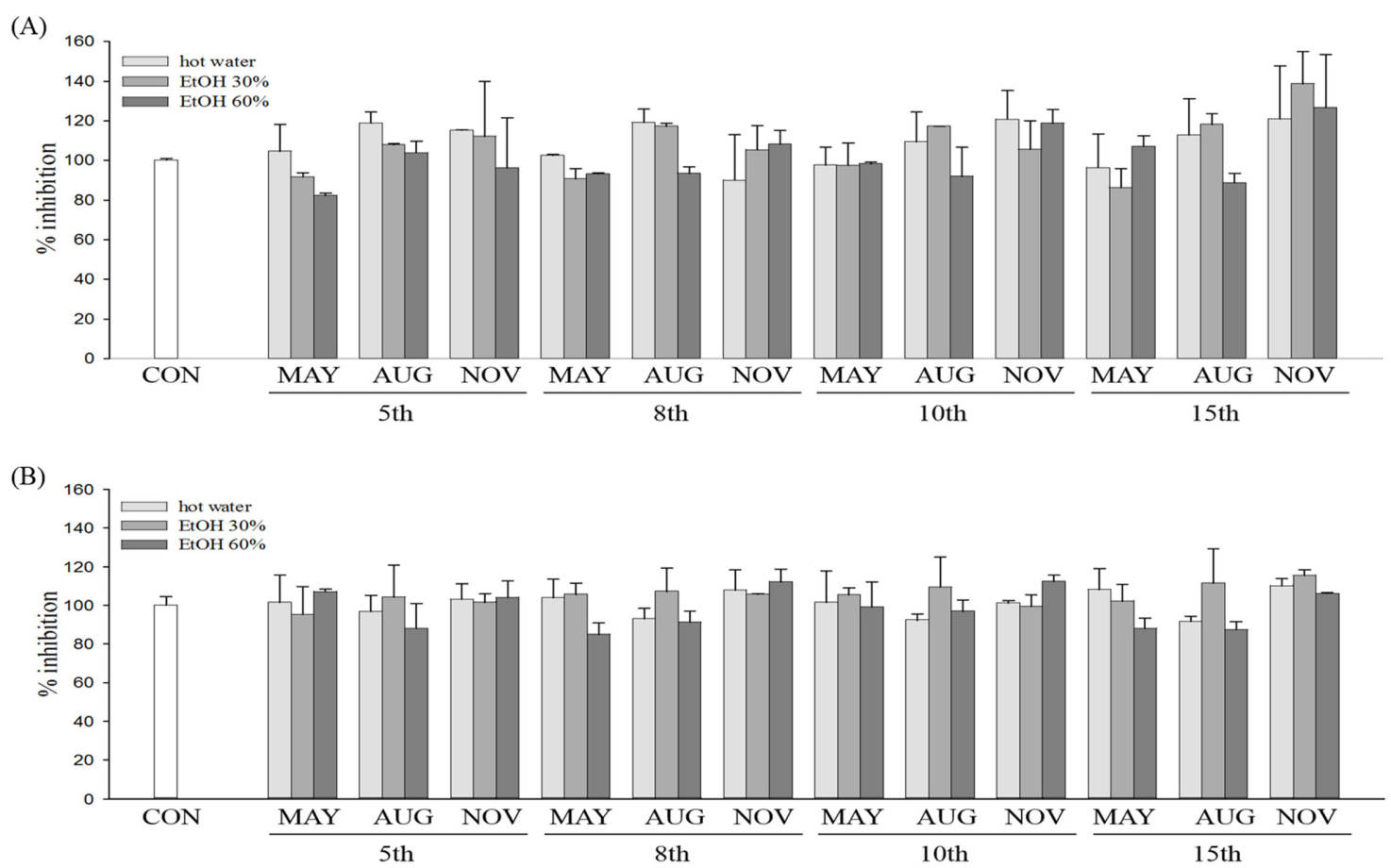

Fig. 1 Cytotoxic effects of extracts of Dendropanax morbifera. (A) RAW 264.7 cells were induced with extracts (50 mM), and (B) HepG2 cells were induced with extracts $(12.5 \mathrm{mM})$ 
(A)

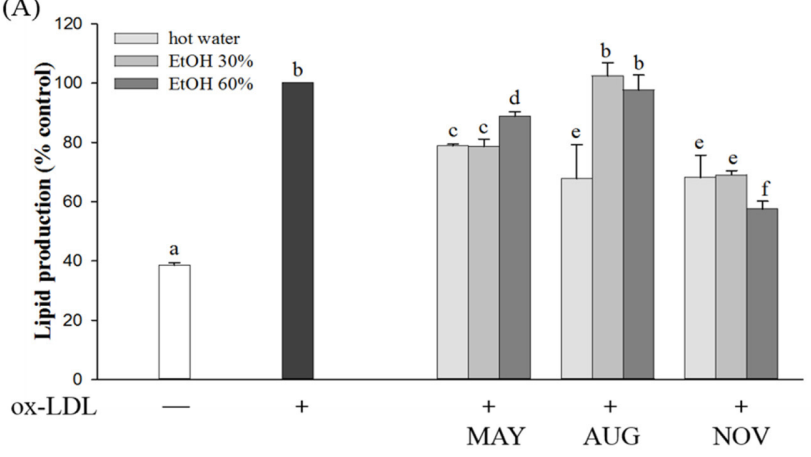

(C)

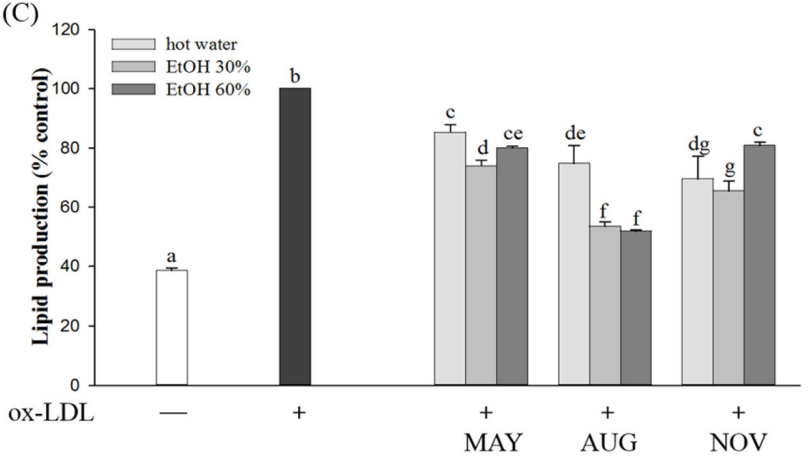

(B)

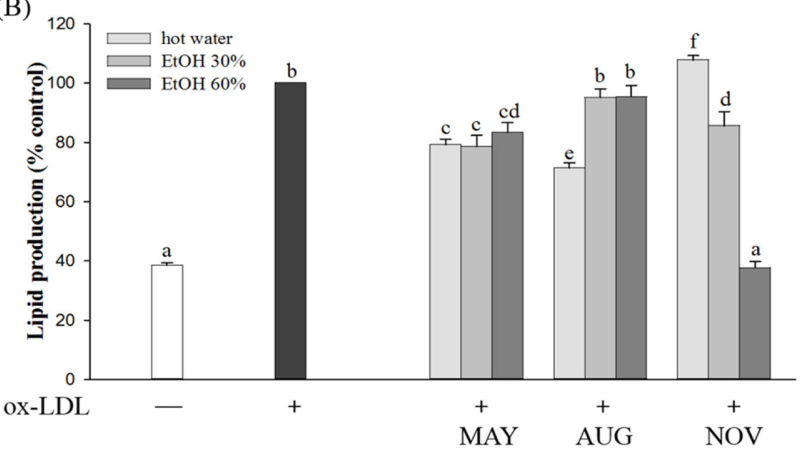

(D)

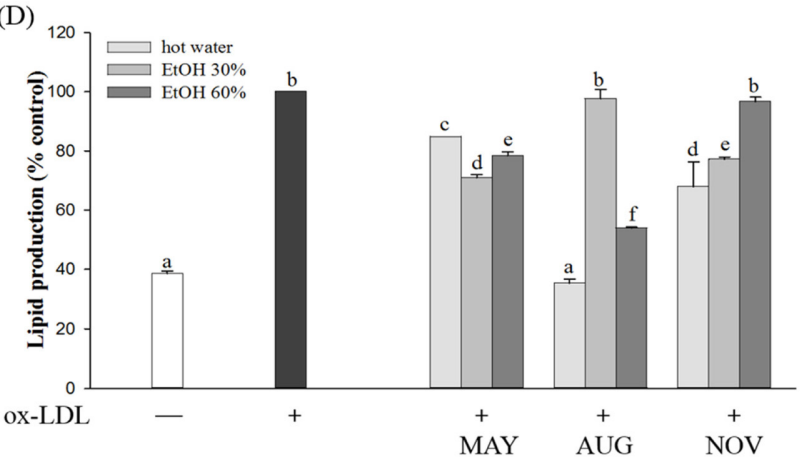

Fig. 2 Lipid accumulation stimulated by ox-LDL in RAW 264.7 cells. Inhibition of lipid production of (A) 5-year-old D. morbifera, (B) 8-year-old, (C) 10 -year-old, and (D) 15 -year-old. Means with different superscript letters are significantly different (Duncan's range test, $p<0.05$ )

농도로 각각 12 시간 처리하였을 때 모든 추출물이 세포 생존율 에 영향을 주지 않았다(Fig. 1A). 이후의 RAW 264.7 cell을 이용한 실험에서는 $50 \mu \mathrm{g} / \mathrm{mL}$ 농도로 진행하였다. $\mathrm{HepG} 2$ cell 세포 또한 황칠 추출물 $12.5 \mu \mathrm{g} / \mathrm{mL}$ 농도로 각각 12시간 처리 시에 모든 추출물이 세포 생존율에 영향을 주지 않았다(Fig. 1B). 따라서 이후 $\mathrm{HepG} 2$ cell을 이용한 실험은 $12.5 \mu \mathrm{g} / \mathrm{mL}$ 농 도로 수행하였다.

\section{산화 저밀도지단백질 억제능 비교}

지질대사를 원활하게 하기 위해서는 혈관 내 저밀도지단백질의 상승을 저해하는 것도 중요하지만, 저밀도지단백질이 산화되는 것을 억제하는 것도 매우 중요하다. 저밀도지단백질이 산화되면 서 혈관 내 플라그 형성을 가속화시키기 때문이다(Mackness 등, 2004). 산화된 저밀도지단백질로 자극을 준 RAW 264.7 cello에 서 황칠나무 잎 추출물이 지방 축적을 억제하는 정도를 ORO 용액을 이용해 확인하였다. 산화된 저밀도지단백질 처리군 대비 지질 축적을 억제하는 능력이 8 년생의 11 월 채취 주정 $60 \%$ 추 출물과 15 년생의 8 월 채취 열수 $100 \%$ 추출물 각각 $63,65 \%$ 로 나타났으며, 이는 산화된 저밀도지단백질을 처리하지 않은 대조 군에서의 지질 축적 억제능 $62 \%$ 보다 높은 수치이다(Figs. $2 \mathrm{~B}$, D). 5 년생 11 월 채취 주정 $60 \%, 10$ 년생 8 월 채취 주정 30 과 $60 \%, 15$ 년생 8 월 채취 주정 $60 \%$ 시료는 $40 \%$ 이상의 억제효 과를 보였다(Fig. 2). 수령이나 채취시기에 관계없이 추출용매에 따라서, 주정 $60 \%$ 의 시료가 가장 높은 억제능을, 그 다음 주정 $30 \%$, 열수 $100 \%$ 순으로 억제능을 나타냈다.

플라보노이드 성분의 일종인 tiliroside와 gnaphaliin은 저밀도
지단백질의 산화를 억제하는 항산화제 역할을 한다고 보고되었 다(Schinella 등, 2007). 또한 sitosterol이 포함된 plant stanol ester spread를 섭취한 건강한 성인 15 명에게서 산화된 저밀도 지단백질의 유의적 감소를 확인했다는 연구결과가 있다(Homma 등, 2003). 산화된 저밀도지단백질의 내포작용을 촉진하고 초기 엔도솜에서의 수송을 촉진시키는 조절을 하는 Ras related protein in brain 5 (Rab5)가 대식세포에서 생성되는 거품세포의 형성을 촉진시킨다. 산화된 저밀도지단백질의 내포작용 및 초기 엔도솜에서의 수송을 막아 죽상 동맥 경화증을 예방할 수 있다 는 보고가 있다(Chan 등, 2017). 결과적으로, $\mathrm{LDL}$ 산화 억제 효과를 나타낸 황칠 나무 잎 8 년생의 11 월 채취 주정 $60 \%$ 추 출물도 죽상 동맥 경화증 예방에 효과가 있을 것으로 예상한다.

\section{간세포 지방 축적 억제능 비교}

에탄올을 처리하여 간독성을 유발한 HepG2 cello에서 황칠나무 잎 추출물이 지방 축적을 얼마나 억제하였는지 확인함으로써 시 료의 지방간 및 지질대사 개선의 효과를 확인하였다. 대조군 대 비 지질 축적 억제효과가 뛰어난 시료는 5 년생의 5 월 채취 주 정 $30 \%$ 와 10 년생 5 월 채취 주정 $60 \%$ 로 각각 $52,50 \%$ 의 억 제능을 보였다(Figs. $3 \mathrm{~A}, \mathrm{C}$ ). 그리고 5 월에 채취한 모든 시료는 $20 \%$ 이상의 억제능을 보였다.

황칠나무 유효 성분인 rutin (Hyun 등, 2013)이 비알콜성 지 방간 마우스 모델의 간세포에서 중성 지방의 함량을 감소시키 고 산화 손상을 완화시킬 수 있음을 나타냈다(Liu 등, 2017b). 유리 지방산에 의해 유도된 HepG2 cell에서 esculetin이 지질 축적을 농도 의존적으로 억제했다는 연구(Park 등, 2017) 뿐만 

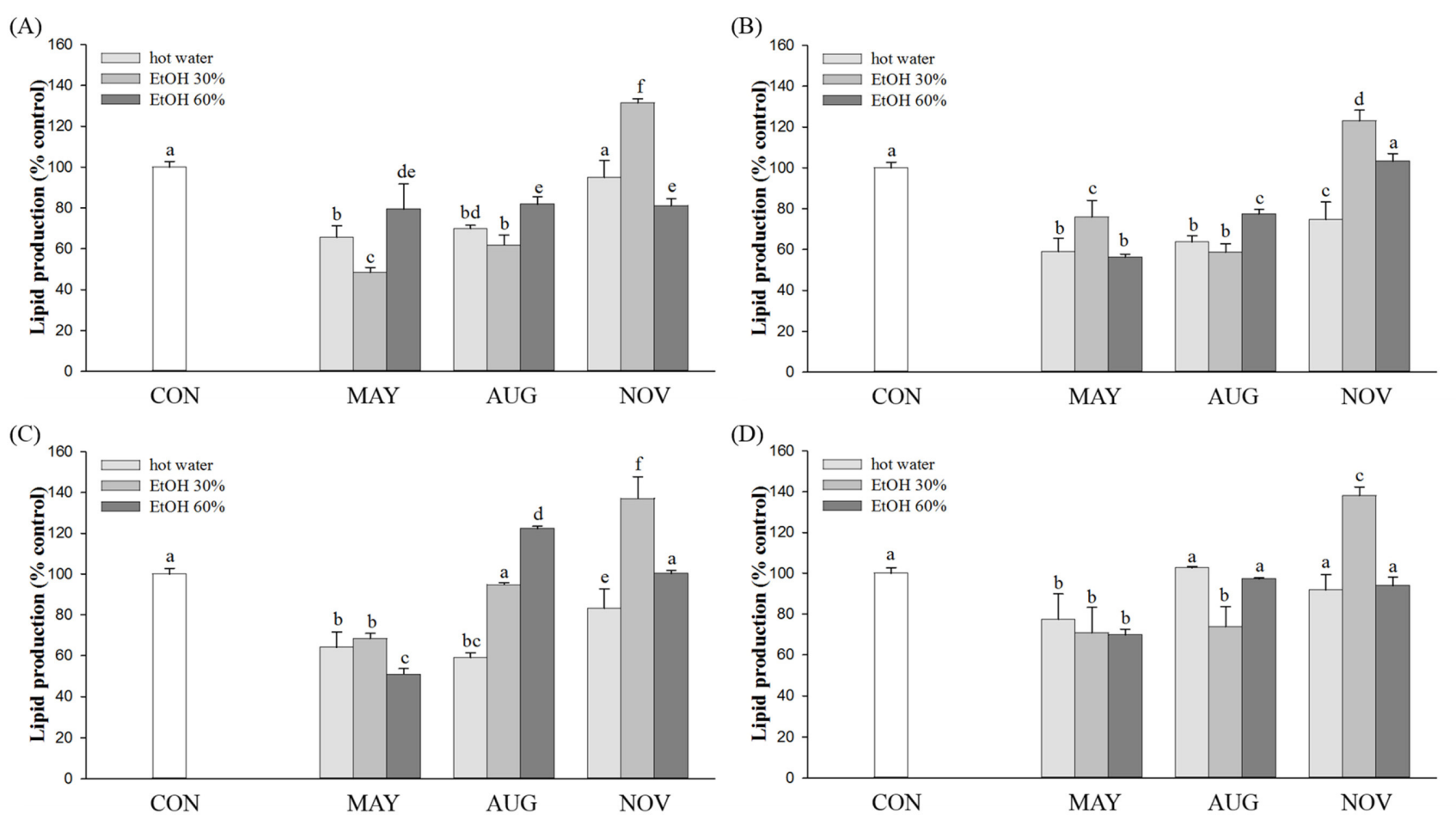

Fig. 3 The Oil-Red-O concentration of lipid production in HepG2 cells induced by hepatotoxicity with ethanol. Protective effect of $D$. morbifera from hepatotoxicity (A) 5-year-old, (B) 8-year-old, (C) 10-year-old, and (D) 15-year-old. Means with different superscript letters are significantly different (Duncan's range test, $p<0.05$ )
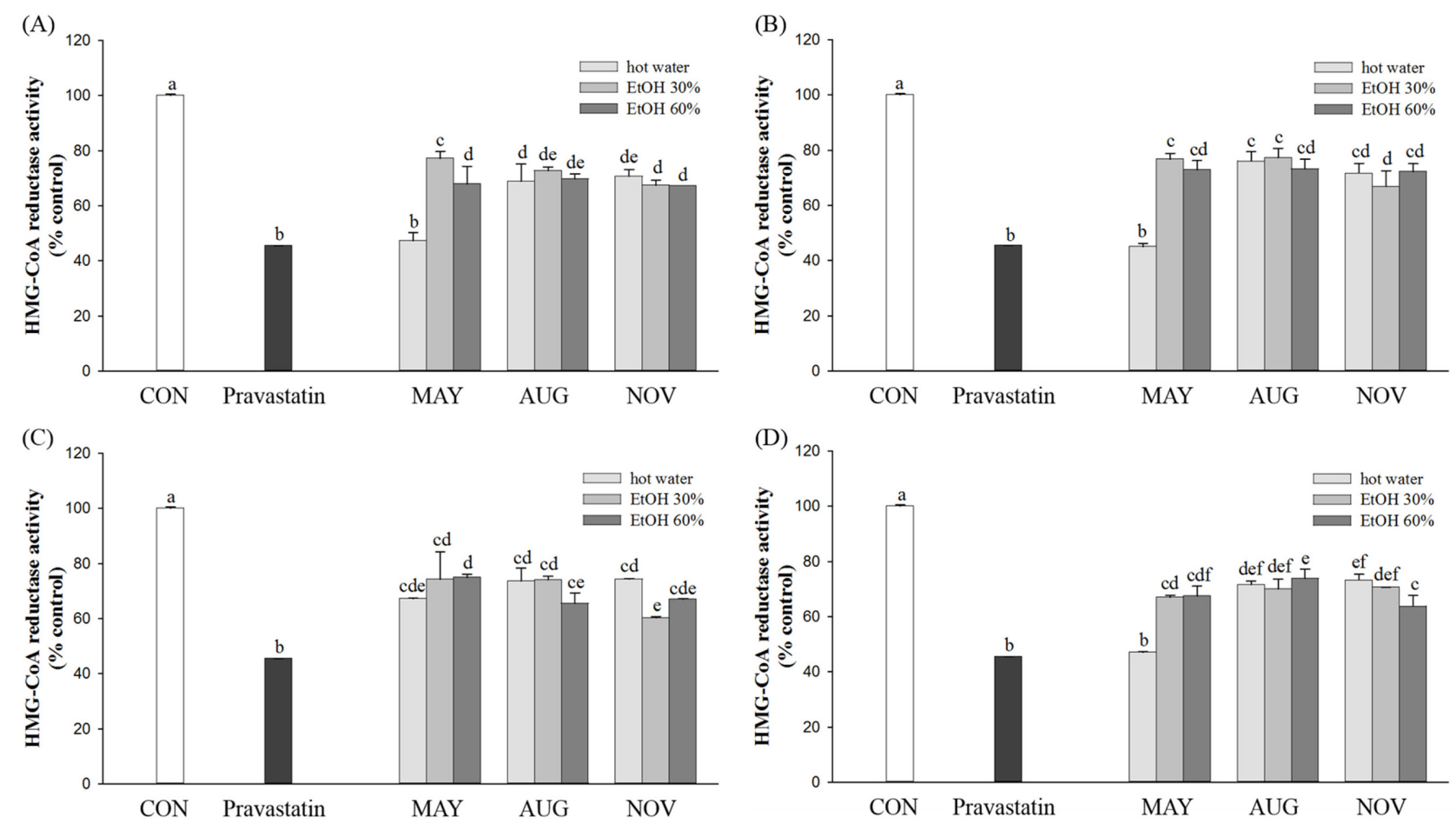

Fig. 4 HMG-CoA reductase activity of D. morbifera. With pravastatin (50nM) as a positive control, it were measured inhibition activity of (A) 5-yearold D. morbifera, (B) 8-year-old, (C) 10-year-old, and (D) 15-year-old. Means with different superscript letters are significantly different (Duncan's range test, $p<0.05$ ) 
(A)

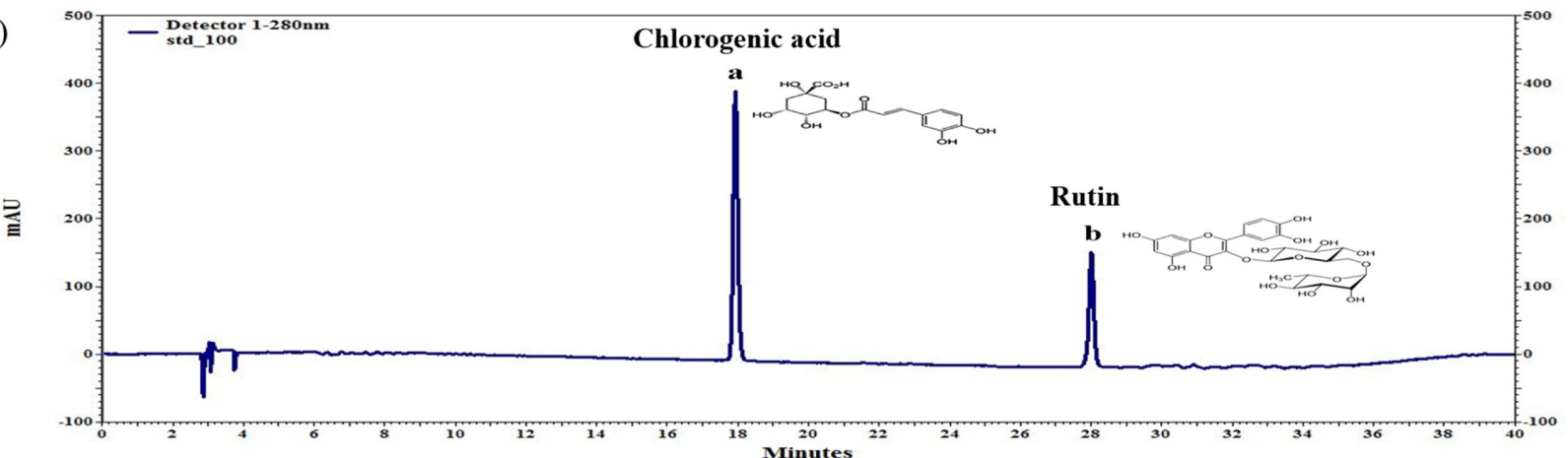

(B)

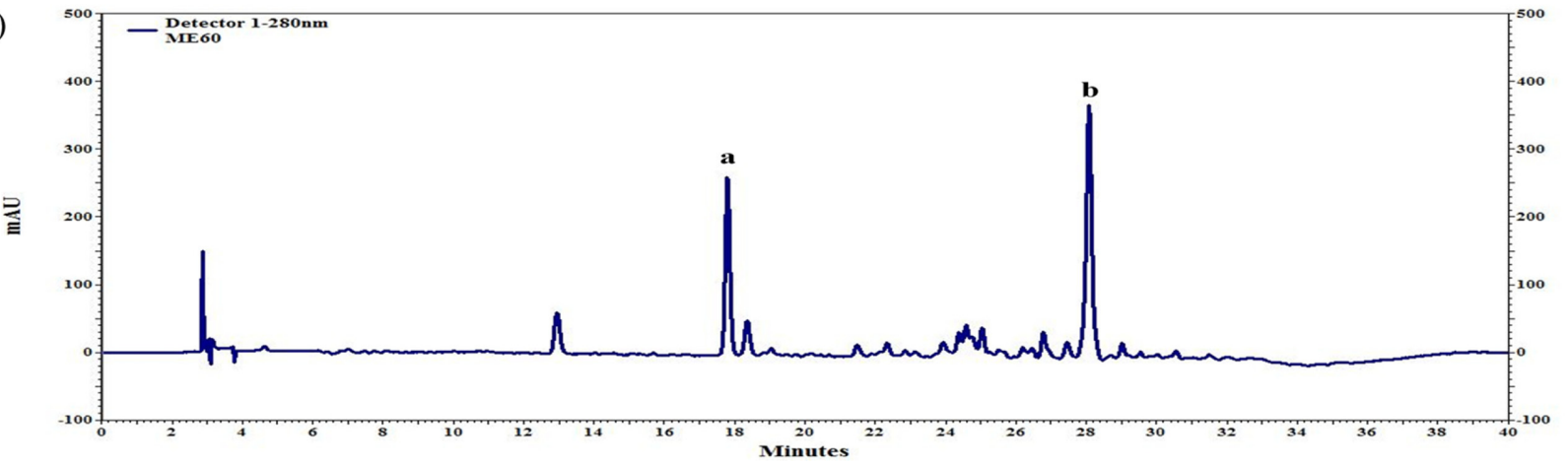

Fig. 5 Chromatogram of flavonoid compounds contained in dendropanax morbifera leaf extract. [A] Standard, [B] representative extract

아니라 R. oldhamii 잎 추출물이 유리지방산으로 유도한 HepG2 cell에서 지질 축적 억제 효과가 있음을 입증하고 지방간 증후 군을 개선한다고 보고되었다(Liu 등, 2017c). 결과적으로, $\mathrm{HepG} 2$ cell에서 지질 축적을 감소시킨 황칠나무 잎 중 5 월에 채취한 추출물들과 10 년생 5 월 채취 주정 $60 \%$ 추출물은 지방 간 개선에 도움이 되는 식품 소재로 개발될 수 있을 것으로 기 대한다.

\section{HMG-CoA reductase 저해능 비교}

콜레스테롤 생합성의 중요한 작용 기전인 $\mathrm{HMGCR}$ 을 저해하여 혈중 콜레스테롤 수치를 낮출 수 있다. HMGCR 저해 활성을 비교한 결과, 모든 시료가 $20 \%$ 가 넘는 억제 효과를 나타냈다 (Fig. 4). 그 중에서도 양성대조군인 statin 계열 pravastatin의 $\mathrm{HMGCR}$ 저해 활성은 $55 \%$ 로 나타났고, 각각 5 년생, 8 년생, 15 년생의 5 월 채취 열수 $100 \%$ 로 추출한 시료에서 $53,55 \%$, $53 \%$ 정도의 억제 효과를 나타냈다(Figs. $4 \mathrm{~A}, \mathrm{~B}, \mathrm{D})$. 나무의 수 령과는 관계없이 5 월에 채취한 시료에서 높은 억제효과를 나타 냈다. 이는 앞선 간세포에서의 지방 축적 억제와 유사한 결과 이다(Fig. 3).

\section{황칠나무 잎 추출물의 주요 flavonoid 분석}

황칠나무에는 chlorogenic acid, caffeic acid, rutin등 폴리페놀 성분이 함유되어 있다(Hyun등, 2013). Ecklonia cava에서 분리 한 폴리페놀 추출물인 Seapolynol ${ }^{\mathrm{TM}}$ 과 Dieckol이 유의적으로 $\mathrm{HMGCR}$ 억제 효과를 보였다고 보고되었다(Yeo 등, 2012). 또 한 폴리페놀 성분 중 caffeic acid, ellagic acid, gallic acid, ferulic acid이 HMGCR 억제효과가 있다는 연구(Lee 등, 2014)
와 $\mathrm{HMGCR}$ 억제제로 천연물질인 폴리페놀 성분이 효과적이라 는 연구가 발표되었다(Lin 등, 2015). Sechium edule shoots의 폴리페놀 물 추출물은 $\mathrm{HMGCR}$ 을 억제하고 콜레스테롤 함량을 감소시켰다(Wu 등, $2014 \mathrm{~b})$. 황칠나무의 $\mathrm{HMGCR}$ 억제능도 황 칠나무 잎에 다량 함유된 폴리페놀 성분의 효과인 것으로 생각 된다. 다만 지질축적 억제 기능을 비교한 결과 황칠나무의 연 생에 따른 차이는 크지 않은 것으로 판단하여 황칠나무 잎에 함유되어 있는 주요 flavonoid 함량은 10 년생 황칠나무 잎 추 출물을 이용하여 추출조건 및 채취시기에 따른 flavonoid 함량 을 확인하였다. Figure 5와 Table 1에서 보여지는 결과와 같이 황칠나무 잎의 열수와 주정 추출물에서는 rutin과 chlorogenic

Table 1 Concentration of chlorogenic acid and rutin ${ }^{1)}$

\begin{tabular}{cccc}
\hline \hline $\begin{array}{c}\text { Sampling } \\
\text { period (Month) }\end{array}$ & $\begin{array}{c}\text { Extraction } \\
\text { solvents }\end{array}$ & $\begin{array}{c}\text { Chlorogenic acid } \\
(\mathrm{mg} / \mathrm{g})\end{array}$ & $\begin{array}{c}\text { Rutin } \\
(\mathrm{mg} / \mathrm{g})\end{array}$ \\
\hline May & Hot water & $14.01 \pm 2.55^{\text {a2) }}$ & $74.00 \pm 8.54^{\text {ad }}$ \\
& EtOH 30\% & $25.87 \pm 2.89^{\mathrm{b}}$ & $110.41 \pm 13.11^{\mathrm{b}}$ \\
& EtOH 60\% & $33.41 \pm 3.15^{\mathrm{c}}$ & $132.33 \pm 16.89^{\mathrm{c}}$ \\
\hline August & Hot water & $17.00 \pm 3.91^{\text {ad }}$ & $60.68 \pm 6.40^{\text {ad }}$ \\
& EtOH 30\% & $22.92 \pm 2.98^{\text {bd }}$ & $79.34 \pm 9.59^{\mathrm{d}}$ \\
& EtOH 60\% & $24.45 \pm 7.41^{\text {bd }}$ & $77.62 \pm 13.55^{\mathrm{d}}$ \\
\hline November & Hot water & $6.54 \pm 2.33^{\mathrm{e}}$ & $28.02 \pm 3.28^{\mathrm{e}}$ \\
& EtOH 30\% & $17.14 \pm 2.96^{\text {ad }}$ & $62.83 \pm 6.49^{\text {ad }}$ \\
& EtOH 60\% & $15.21 \pm 5.72^{\mathrm{a}}$ & $56.95 \pm 6.11^{\mathrm{a}}$ \\
\hline
\end{tabular}

${ }^{1)}$ Means \pm SD

${ }^{2)}$ Means with different superscript letters are significantly different (Duncan's range test, $p<0.05$ ) 
acid가 확인되었으며 rutin의 함량이 chlorogenic acid에 비해 약 5 배 이상 많이 함유되어 있는 것으로 판단된다. 이들 성분의 함 량은 추출용매에 주정의 비율이 높을수록 많이 함유되어 있는 것으로 확인된다. 또한 8 월이나 11 월에 채취한 잎보다는 5 월에 채취한 잎에 rutin과 chlorogenic acid 성분이 많이 함유되어 있 는 것으로 확인되었다. 이러한 결과를 토대로 봤을 때, 주정추 출물이 황칠의 플라보노이드 성분을 효과적으로 추출할 수 있 는 용매라고 판단되며 이는 지질축적 억제 활성과 일치하는 경 향을 보이고 있다. Rutin과 chlorogenic acid 성분들 이외에 황 칠나무 추출물들에 함유되어 있는 다른 성분들의 차이와 활성 에 주요하게 기여하는 성분 대해서는 추가적으로 연구가 진행 되어야 할 것이다.

\section{초 록}

이 연구는 고지혈증에 대한 생리 반응의 조절과 관련하여 Dendropanax morbifera 잎의 효과를 비교하기 위한 것이다. 추 출물은 표본 연령, 수확시기, 추출 방법에 따라 달랐다. 이 추 출물이 처리된 RAW 264.7 세포는 산화 저밀도 지단백질에 의 해 자극되었고, 세포 지질 축적은 Oil Red O (ORO) 염색법을 사용하여 정량화되었다. HepG2 세포에서 에탄올을 사용하여 독 성을 유도한 다음, 상기와 같이 지질 축적을 정량화하였다. 추 출물의 3-hydroxy-3-methylglutaryl coenzyme A (HMG-CoA) reductase 억제 활성을 측정하였다. RAW 264.7 세포에서 가장 지질 축적을 억제한 시료는 8 년생 11 월 채취 주정 $60 \%$ 추출물 로 처리된 세포에서 관찰되었다. 에탄올로 유도한 $\mathrm{HepG} 2$ 세포 에서 가장 큰 보호효과를 나타낸 시료는 5년생 5월 채취 주정 $30 \%$ 추출물이었다. 가장 강력한 $\mathrm{HMG}-\mathrm{CoA}$ reductase 억제 작 용을 한 시료는 8 년생 5 월 채취 열수 $100 \%$ 추출물이다. 전체 적으로 봤을 때 지질 축적 억제는 주정 추출물에서, 콜레스테 롤 합성 효소 저해 효과는 열수추출물에서 좋은 효과를 보여 이들 원료를 기반으로 지질 대사 개선 기능성 원료를 개발할 수 있을 것이라 기대한다.

Keywords 3-하이드록시-3-메틸글루티릴-보조효소 A 환원효소 · 고지혈증 · 산화저밀도지단백질 · 지질축적 · 황칠

감사의 글 본 결과물은 제주자원식물황칠사업단의 지원을 받아 연구되었습니다.

\section{References}

Akram M, Kim KA, Kim ES, Syed AS, Kim CY, Lee JS, Bae ON (2016) Potent Anti-inflammatory and Analgesic Actions of the Chloroform Extract of Dendropanax morbifera Mediated by the Nrf2/HO-1 Pathway. Biol Pharm Bull 39: 728-736

An NY, Kim JE, Hwang DY, Ryu HK (2014) Anti-diabetic effects of aqueous and ethanol extract of Dendropanax morbifera Leveille in streptozotocininduced diabetes model. J Nutr Health 47: 394-402

Chan L, Hong J, Pan J, Li J, Wen Z, Shi H, Ding J, Luo X (2017) Role of Rab5 in the formation of macrophage-derived foam cell. Lipids Health Dis 16: 170

Choi JH, Kim DW, Park SE, Lee HJ, Kim KM, Kim KJ, Kim MK, Kim SJ, Kim S (2015) Anti-thrombotic effect of rutin isolated from Dendropanax morbifera Leveille. J Biosci Bioeng 120: 181-186

Choi WS, Chang SH, Kim JE, Lee SE (2013) Hypolipidemic Effects of Scoparone and Its Coumarin Analogues in Hyperlipidemia Rats Induced by High Fat Diet. J Korean Soc Appl Biol Chem 56: 647-653

Chung IM, Song HK, Kim SJ, Moon HI (2011) Anticomplement activity of polyacetylenes from leaves of Dendropanax morbifera Leveille. Phytother Res 25: 784-786

Coseteng MY, Lee CY (1987) Changes in Apple Polyphenoloxidase and Polyphenol Concentrations in Relation to Degree of Browning. J Food Sci 52: 985-989

Goldstein JL, Schrott HG, Hazzard WR, Bierman EL, Motulsky AG (1973) Hyperlipidemia in coronary heart disease. II. Genetic analysis of lipid levels in 176 families and delineation of a new inherited disorder, combined hyperlipidemia. J Clin Invest 52: 1544-1568

Homma Y, Ikeda I, Ishikawa T, Tateno M, Sugano M, Nakamura H (2003) Decrease in plasma low-density lipoprotein cholesterol, apolipoprotein $\mathrm{B}$, cholesteryl ester transfer protein, and oxidized low-density lipoprotein by plant stanol ester-containing spread: a randomized, placebo-controlled trial. Nutr 19: 369-374

Hwang KA, Hwang YJ, Hwang IG, Song J, Cho SM (2017) Cholesterollowering effect of astringent persimmon fruits (Diospyros kaki Thunb.) extracts. Food Sci Biotechnol 26: 229-235

Hyun TK, Kim MO, Lee H, Kim Y, Kim E, Kim JS (2013) Evaluation of anti-oxidant and anti-cancer properties of Dendropanax morbifera Leveille. Food Chem 141: 1947-1955

Jun HJ, Wen Q, Lee JH, Jeun J, Lee HJ, Lee KG, Oh SK, Lee SJ (2012) Effects of Korean Black Raspberry Wines on Hepatic Cholesterol Metabolism and Retinal Vascular Formation In Vitro. J Korean Soc Appl Biol Chem 55: 249-257

Kim YK, Kim YB, Kim JK, Kim SU, Park SU (2014) Molecular Cloning and Characterization of Mevalonic acid (MVA) Pathway Genes and Triterpene Accumulation in Panax ginseng. J Korean Soc Appl Biol Chem 57: 289-295

Lee JW, Park C, Han MH, Hong SH, Lee TK, Lee SH, Kim GY, Choi YH (2013) Induction of human leukemia U937 cell apoptosis by an ethanol extract of Dendropanax morbifera Lev. through the caspase-dependent pathway. Oncol Rep 30: 1231-1238

Lee MJ, Lee SJ, Choi HR, Lee JH, Kwon JW, Chae KS, Jeong JT, Lee TB (2014) Improvement of Cholesterol and Blood Pressure in Fruit, Leaf and Stem Extracts from Black Raspberry in vitro. Korean J Med Crop Sci 22: 177-187

Lee SY, Choi EJ, Bae DH, Lee DW, Kim S (2015) Effects of 1-tetradecanol and $\beta$-sitosterol Isolated from Dendropanax morbifera Lev. on Skin Whitening, Moisturizing and Preventing Hair Loss. J Soc Cosmet Sci Korea 41: 73-83

Lin SH, Huang KJ, Weng CF, Shiuan D (2015) Exploration of natural product ingredients as inhibitors of human HMG-CoA reductase through structure-based virtual screening. Drug Des Devel Ther 9: 3313-3324

Liu Q, Pan R, Ding L, Zhang F, Hu L, Ding B, Zhu L, Xia Y, Dou X (2017a) Rutin exhibits hepatoprotective effects in a mouse model of nonalcoholic fatty liver disease by reducing hepatic lipid levels and mitigating lipid-induced oxidative injuries. Int Immunopharmacol 49: 132-141

Liu YL, Lin LC, Tung YT, Ho ST, Chen YL, Lin CC, Wu JH (2017b) Rhododendron oldhamii leaf extract improves fatty liver syndrome by increasing lipid oxidation and decreasing the lipogenesis pathway in mice. Int J Med Sci 14: 862-870

Liu Z, Zhu H, Dai X, Wang C, Ding Y, Song P, Zou MH (2017c) Macrophage Liver Kinase B1 Inhibits Foam Cell Formation and Atherosclerosis. Circ Res 121: 1047-1057

Lo WC, Ku CC, Chiou ST, Chan CC, Chen CL, Lai MS, Lin HH (2017) Adult mortality of diseases and injuries attributable to selected metabolic, lifestyle, environmental, and infectious risk factors in Taiwan: a comparative risk assessment. Popul Health Metr 15: 17

Mackness B, Hine D, Liu Y, Mastorikou M, Mackness M (2004) 
Paraoxonase-1 inhibits oxidised LDL-induced MCP-1 production by endothelial cells. Biochem Biophys Res Commun 318: 680-683

Mo JH, Oh SJ (2013) Tyrosinase Inhibitory Activity and Melanin Production Inhibitory Activity of the Methanol Extract and Fractions from Dendropanax morbifera Lev. Kor J Aesthet Cosmetol 11: 275-280

Moon HI (2011) Antidiabetic effects of dendropanoxide from leaves of Dendropanax morbifera Leveille in normal and streptozotocin-induced diabetic rats. Hum Exp Toxicol 30: 870-875

Park Y, J, Sung JH, Yang JW, Ham HM, Kim YH, Jeong HS, Lee JS (2017) Inhibitory effect of esculetin on free-fatty-acid-induced lipid accumulation in human HepG2 cells through activation of AMP-activated protein kinase. Food Sci Biotechnol 26: 263-269

Perla FM, Prelati M, Lavorato M, Visicchio D, Anania C (2017) The Role of Lipid and Lipoprotein Metabolism in Non-Alcoholic Fatty Liver Disease. Children (Basel) 4: 1-14

Qiao W, Zhao C, Qin N, Zhai HY, Duan HQ (2011) Identification of transtiliroside as active principle with anti-hyperglycemic, anti-hyperlipidemic and antioxidant effects from Potentilla chinesis. J Ethnopharmacol 135: $515-521$

Ramoglu S, Yoldemir T, Atasayan K, Yavuz DG (2017) Does cardiovascular risk vary according to the criteria for a diagnosis of polycystic ovary syndrome? J Obstet Gynaecol Res 43: 1848-1854

Rudkowska I, Abumweis SS, Nicolle C, and Jones PJ (2008) Cholesterollowering efficacy of plant sterols in low-fat yogurt consumed as a snack or with a meal. J Am Coll Nutr 27: 588-595

Schinella GR, Tournier HA, Manez S, De Buschiazzo PM, Del Carmen Recio M, Rios JL (2007) Tiliroside and gnaphaliin inhibit human low density lipoprotein oxidation. Fitoterapia 78: 1-6
Tan XR, Ho Kyung (2015) Effects of Dendropanax morbifera Leaf Extracts on Lipid Profiles in Mice Fed a High-Fat and High-Cholesterol Diet. J Korean Soc Food Sci Nutr 44: 641-648

Won BY, Shin KY, Ha HJ, Yun YS, Kim YR, Lee HG (2015) Changes in Nutritional Composition of Dropwort (Oenanthe javanica) Ethanol Extracts. J Korean Soc Food Sci Nutr 44: 882-887

Wu C, Luan H, Zhang X, Wang S, Zhang X, Sun X, Guo P (2014a) Chlorogenic acid protects against atherosclerosis in ApoE-/- mice and promotes cholesterol efflux from RAW 264.7 macrophages. PLoS One 9: e95452

Wu CH, Ou TT, Chang CH, Chang XZ, Yang MY, Wang CJ (2014b) The polyphenol extract from Sechium edule shoots inhibits lipogenesis and stimulates lipolysis via activation of AMPK signals in HepG2 cells. J Agric Food Chem 62: 750-759

Xu S, Huang Y, Xie Y, Lan T, Le K, Chen J, Chen S, Gao S, Xu X, Shen X, Huang H, Liu P (2010) Evaluation of foam cell formation in cultured macrophages: an improved method with Oil Red O staining and DiIoxLDL uptake. Cytotechnology 62: 473-481

Xu Z, Dong A, Feng Z, and Li J (2017) Interleukin-32 promotes lipid accumulation through inhibition of cholesterol efflux. Exp Ther Med 14: 947-952

Yao HR, Liu J, Plumeri D, Cao YB, He T, Lin L, Li Y, Jiang YY, Li J, Shang J (2011) Lipotoxicity in HepG2 cells triggered by free fatty acids. Am J Transl Res 3: 284-291

Yeo AR, Lee J, Tae IH, Park SR, Cho YH, Lee BH, Shin HC, Kim SH, Yoo YC (2012) Anti-hyperlipidemic Effect of Polyphenol Extract (Seapolynol ( )) and Dieckol Isolated from Ecklonia cava in in vivo and in vitro Models. Prev Nutr Food Sci 17: 1-7 